\title{
FACTORS INFLUENCING COOPERATIVE BUSINESS INNOVATION THROUGH INFORMATION TECHNOLOGY ADOPTION; A CONCEPTUAL FRAMEWORK DEVELOPMENT
}

\author{
ROSLI SALEH * \\ CHE ADNAN CHE DAUD ** \\ rosli.s@umk.edu.my
}

\begin{abstract}
Abstrak
Kesan dan akibat teknologi maklumat (IT) dalam operasi perniagaan telah menjadi topik perbincangan yang penting di seluruh dunia. Nampaknya impak IT sangat penting kepada mana-mana organisasi perniagaan untuk meningkatkan kecekapan dan produktiviti. Koperasi, sebagai kategori penetapan perniagaan, harus juga mengadoptasi IT sebagai alat penting untuk terus berinovasi proses perniagaan mereka sebagai alat untuk kelestarian dalam era globalisasi. Walau bagaimanapun, setakat mana koperasi-koperasi ini telah menerima teknologi masih perlu dipelajari. Beberapa soalan berkaitan dengan penggunaan IT dan faktorfaktor yang mempengaruhi serta kesan impak IT terhadap prestasi perniagaan di kalangan koperasi perlu dijawab. Oleh itu, kertas kerja ini bertujuan untuk mengkaji faktor-faktor yang mempengaruhi penerimaan IT dan kesan prestasi IT dalam operasi perniagaan koperasi. Kajian ini juga bertujuan untuk mencabar andaian implikasinya dalam model penerimaan teknologi, iaitu tidak ada kesan yang sederhana dalam hubungan antara niat tingkah laku dan penggunaan sebenar sistem. Khususnya, kajian ini mengkaji kesan faktor-faktor sebelumnya-efikasi diri, imej, norma subjektif, dan kesedaran tentang persepsi; dan pengaruh sokongan pengurusan moderator atas niat dan pengangkatan. Selanjutnya, kajian ini juga bertujuan untuk mendapatkan lebih banyak lagi kesan impak yang diterima oleh IT dalam aktiviti perniagaan koperasi yang dipercayai mempengaruhi secara langsung atau tidak langsung proses penerimaan.
\end{abstract}

Kata kunci: pengambilan teknologi maklumat, koperasi, model penerimaan teknologi

\footnotetext{
* Profesor Madya di Pusat Penyelidikan Keusahawanan Dan Inovasi Global \& Fakulti Keusahawanan Dan Perniagaan, Universiti Malaysia Kelantan

** Pelajar Pascasiswazah di Fakulti Keusahawanan Dan Perniagaan, Universiti Malaysia Kelantan
} 


\begin{abstract}
The emergence and consequences of information technology (IT) in business operation has become pertinent discussion topics worldwide. It seems that the impact of IT is very crucial to any business organization towards improving its efficiency and productivity. Cooperatives, as a category of business settings, have to also adopt the new IT as an important tool to further innovate their business process as a means for sustainability in the globalize era. But nevertheless, to which extent these cooperatives have adopted the technology remains to be studied. Some questions with regard to the adoption of IT and the influencing factors as well as perceived impacts of IT on business performance among cooperatives need to be answered. Hence, this paper intended to study factors that influence IT adoption and perceived performance effects of IT in cooperatives business operation. This study also aims to challenge the implicit assumption in technology acceptance model, i.e. non-existing of moderating effects on the relationship between behavioral intention and actual use of system. Specifically, the study examines the effects of prior factors-self-efficacy, image, subjective norm, and awareness on perception; and the influence of moderator-top management support on intention and adoption. Subsequently, the study also intended to seek further light on the perceived impacts of IT adoption in cooperative business activities which is believed to affect directly or indirectly the adoption process.
\end{abstract}

Keywords: information technology adoption, cooperatives, technology acceptance model

\footnotetext{
* Associate Professor at Global Entrepreneurship and Research Innovations Center (GERIC) \& Faculty of Entrepreneurship and Business, Universiti Malaysia Kelantan

** Postgraduate Student at Faculty of Entrepreneurship and Business, Universiti Malaysia Kelantan

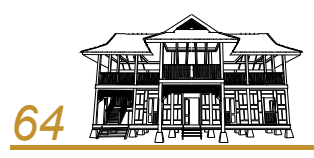




\subsection{Introduction}

The contribution of social enterprises as well as cooperative (also co-operative or co-op) to socialeconomic development has been globally appreciated. A Cooperative is a business entity owned and run by a team of individuals for their shared benefit. According the International Cooperative Alliance (ICA), a cooperative refers as an "autonomous association of persons united voluntarily to meet their common economic, social and cultural needs and aspirations, through a jointly owned and democratically controlled enterprise" (United Nation [UN], 2011). Operationally, members of cooperative have dominant control over the cooperatives compared to other form of business organizations. A cooperative's setting looks simpler in terms of decision making system, governance, the directors as representative of its members: in which the members act as principal, and the managements as agent (Torgerson, Reynolds, \& Gray, 1997).

The number of cooperatives and their members are continuously increasing particularly in the current economic condition, for securing investment and cultivating social equity. Cooperatives and social enterprises are the world's finest optimism of realizing harmony, affluence, and social fairness in this new era (Curl, 2010). Consequently, after the industrial revolution, the number of cooperatives is rising and the idea of business cooperation has spread into various sectors and economic activities. Nowadays, cooperatives continue to dynamically generate and create employment for socialeconomic well being.

Since past decade, this type of business organization has widely being spread all over the world due to its considerable performance. It is estimated that from 74 countries in all continents which represent $79 \%$ of the world's population, where 250 million individuals work within the scope of cooperatives business activities: equivalent to $8.73 \%$ of the world's employed population that is substantially higher if compared to 100 million jobs offered in 1990s (Roelants, Hyungsik, \& Terrasi, 2014).

In reality, a cooperative function in a similar manner with other commercial firms, which is to serve for the market demand. They also need to react to the new changes in business environment. According to Hebert (1994), fast changes in technology, demands firms to be more responsive to the human factors, which very much determine the successful technology adoption by the organization. In the meantime, a firm's directions is determined by its leaders consisting of chief executive officers and top management. In that sense, cooperative managers also need to play similar role in bringing success to the organizations. In other word, managers also need to manage various changes that can potentially affect their organization in the form of technology, globalization, and lifestyle (Mhd Sarif \& Ismail, 2010 as cited Hitt, Black and Porter (2009, pp.26-31). 

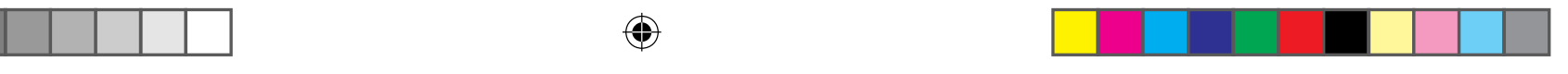

At present, the emergence of Information Technology (IT) in recent years has given substantial impact on global business organizations. Many scholars have confirmed the dramatic improvement in business efficiency and productivity as a result of the use of IT (Shah Alam \& Mohammad Noor, 2009; Niehm et al., 2010). Previous research discovered that IT adoption has improved productivity, generated useful value to customers, accessed to market, and enhanced organizational performance (Hitt \& Brynjolfsson, 1996; Chairoel, Widyarto, \& Pujani, 2015). A firm (including cooperative) which employs business strategies through empowering IT or Information System adoption has a significant effect on its performance (Shu-Hung Hsu, 2012). This performance is commonly known as operational performance, a mediating factor which eventually effects financial performance of any business organization.

However, besides significant role of IT in business enterprises particularly, Cheuk (2012) reports that only about $50 \%$ of the cooperatives adopt IT in their operations. The question of why some of the cooperatives adopt the IT while others still not adopting it are still being understudied. In fact, a lot of studies have been conducted to recognize and evaluate these factors by researchers since previous couple of decades (Legris, Ingham, \& Collerette, 2001).

Therefore, studies on adoption and diffusion of IT have become increasingly critical to improve understanding and prediction of IT acceptance and utilization. It is also crucial to associate impacts on adoption or implementation of IT into cooperative business operational performance because of its substantial financial payout. Nevertheless, little studies were conducted to explain which factors effect IT adoption in cooperative business. Additionally, not many studies were found to seek to explain perceived performance effects on IT adoption in cooperative entities. This study therefore, attempted to fill the research gap by investigating factors influencing the relationship between variables and IT adoption within the cooperative organizations and consequently establishing the relationship. In turn, the research is also conducted to explore perceived impacts from the IT adoption on cooperative business performance.

\subsection{Literature Review}

Nowadays, IT has been known to play a vital role in improving economic growth and enhancing efficiency. In the 1960s and 1970s, research showed great support from telecommunications technology to economic production and distribution, public service delivery, and government supervision. In the next decade of 1980s, information were acknowledged as a new critical factor of production. Subsequently, in the 1990s economic activity such as improved of demand has triggered growing amount of information, coupled with rapid technological revolution made IT substantial to 
organizations' competitiveness and growth (Guislain, Qiang, Lanvin, Minges, \& Swanson, 2006). A firm's competitiveness and survival depends on its ability to react and adapt to an innovation. Through these technologies, an organization could improve efficiency and quality of business processes (Soto-Acosta et al. 2010; Ramayah et al. 2011; Trigueros-Preciado, Pérez-González, \& Solana-González, 2013).

The argument was supported by Hashim (2007) who stressed that companies these days must equip themselves and their employees with knowledge-based economy in order to remain competitive in the global market. In conjunction with that, IT is seen as an important tool for business organizations to face new business challenges. In the global worldwide market, IT offers practical solutions to the obstacles faced by organizations with respect to the productivity of the workers and the quality of service (Napoleon, 1997; Qiang, Clarke, \& Halewood, 2006). Cron and Sobol (1983) justified that larger firms which procure or lease their computers and then optimize the use of software were more likely to lower their operating costs and, eventually increase their overall performance (Turnbow, 1996).

Recent IT developments may have promote to a business organization's competitiveness and efficiency through application of sophisticated IT software, such as Customer Resource Management (CRM) and Electronic Data Interchange (EDI), which has empowered organizations to store, share, and use their subscribed information easily (Guislain et al., 2006). In the agriculture sector for instance, Farmers Organizations (FOs) were linked via integrated supplies, production, processing and marketing activities, coupled with application of IT in order to improve delivery system of both agencies (Ahmad,2006).

In summary, the development process of IT and its substantial roles are currently being the prerequisite to cooperative businesses as well, in which they may require to revise their business process in order to be more efficient, effective, and productive. Thus, to improve the adoption and acceptance processes, organization such as cooperative should be aware of their potential individual and organizational influences. Davis (1993) reveals that failure or success of any adoption process is determined by user's acceptance or rejection of any system. Since IT adoption in organization is determined by human characteristics (internal beliefs and external influences), measuring these factors is important to improve the understanding on what has contributed to the process. 
Another related subject which was discussed among IT researchers and practitioners is the impacts of IT adoption on business performance. Such performance could be measured through direct or indirect impacts (Bayo-Moriones, Billon, \& Lera-Lopez, 2013). Most firms allocate substantial resources in their IT migration in order to improve their competitiveness in current and future markets (Eckhardt, Laumer, \& Weitzel, 2009). Past studies, notwithstanding, observed contradiction in the findings due to restrictive IT and organizational performance measures (Paopun, 2001). Moreover, in many cases, findings have also been vague and inconclusive.

Furthermore, the adoption of IT, as heavily debated among IT scholars and practitioners, was due to its huge financial investment needed by any business organization. This study is purposely conducted in order to investigate the relationship between adoption (i.e. represents by actual use of IT) and its perceived impacts on business performance.

\subsection{Theoretical background and research hypotheses}

Most of models proposed in technology adoption are established from theories coming from disciplines such as behavioral science and social psychology. This study will also develop a conceptual framework based on the technology acceptance model (TAM). Figure 1 shows the proposed model, which uses TAM as the main theoretical foundation. However, previous studies recommended that the original TAM need to also consider other related theories in order to increase its predictive power. This framework attempts to build a parsimonious research model by including some other prior factors, which were studied in TAM2 (i.e. subjective norm and image). However the test for the variables does not restricted to only perceived usefulness as indicated in TAM2. The relationship between the similar variables with perceived ease of use is also accounted for. TAM2, as compared to the original TAM, obviously incorporates additional theoretical constructs bridging the social influence processes (subjective norm and image), while cognitive instrumental processes, i.e., perceived ease of use, remains unchanged. Another essential test to the suggested in this study is the inclusion of the awareness factor as an antecedent to both perceived usefulness and perceived ease of use. The variable which was proposed by Agarwal \& Prasad (1998) who investigated its relationship with perception, which was adapted from Roger's diffusion of innovation theory. 


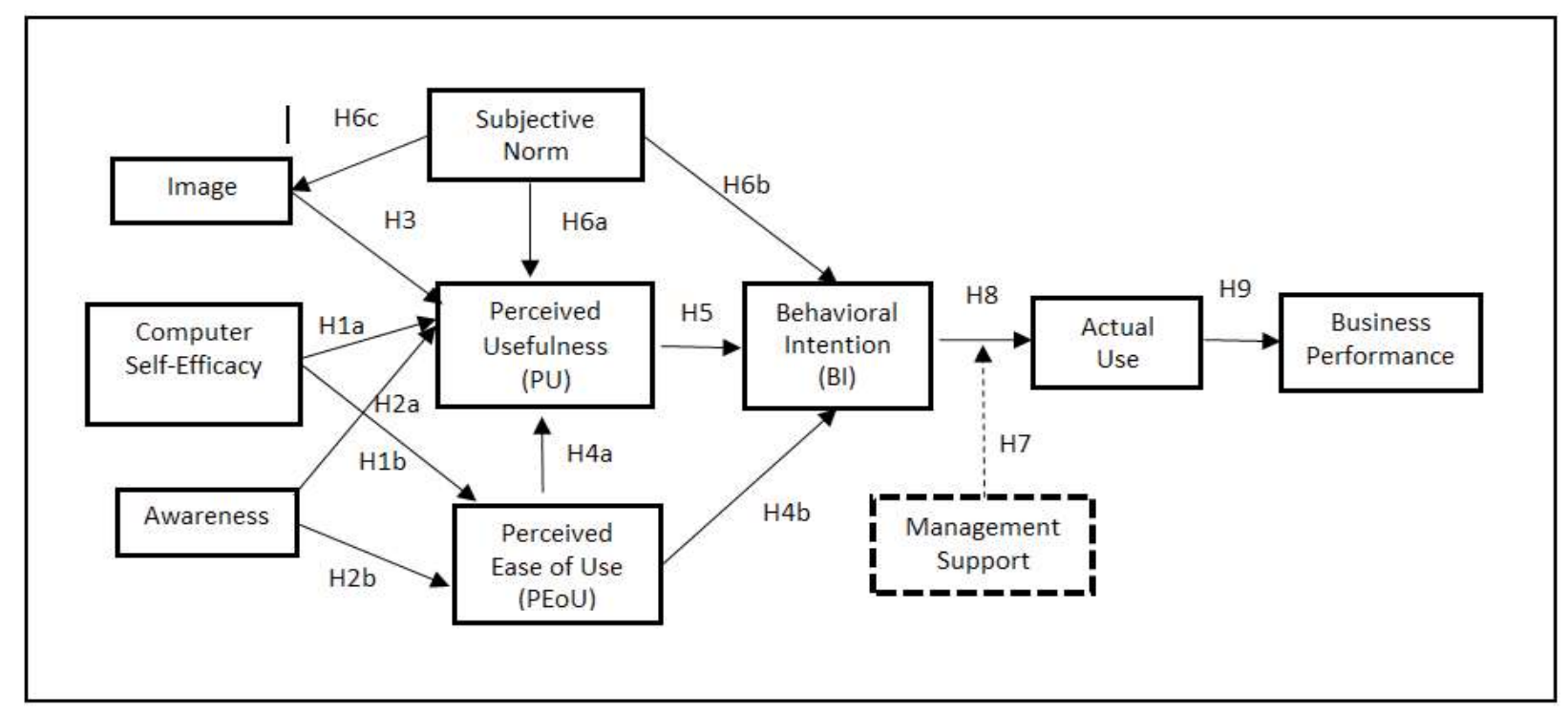

Figure 1: Proposed Conceptual Framework of the Study 
The above conceptual framework of this study is depicted as in Figure 1.0. The development of the framework begins with identifying potential factors that might relate to IT adoption in cooperatives. Even if TAM has consistently been applied to the number of technologies, this study deliberately classifies IT into four major categories (Lee, Kozar, \& Larsen, 2003), namely a) communication systems, b) general-purpose systems, c) office systems, and d) specialized business systems. Table 1.0 summarizes major classifications of IT as broadly studied using the TAM.

Lee et al. (2003) have segregated communication systems as e-mail, v-mail, fax, dial-up systems, social media, and other related systems. General-purpose systems comprise of windows, personal computers, microcomputers, workstations, the Internet, and other computer facilities. Office systems refer to common software that are often used in workplace such as word processors, spreadsheets, and the like. While specialized business system incorporates special task systems, and mostly organization customized systems such as Case tools, GSS, MRP II, Expert Systems, and etc. The details of the definition are showed as in Table 1.0.

Table 1: Summary of IT Categories applied in TAM Studies

\begin{tabular}{|l|c|ll|ll|}
\hline $\begin{array}{c}\text { Type of } \\
\text { category }\end{array}$ & \% of IT & & IT for each category & \multicolumn{1}{c|}{ References } \\
\hline & & $\bullet$ & E-mail & $\bullet$ & Karahanna and Straub [1999], \\
& & $\bullet$ & V-mail & Straub [1994] \\
Communication & 20 & $\bullet$ & FAX & $\bullet$ & Karahanna and Limayem [2000] \\
Systems & & $\bullet$ & Dial-up Systems & $\bullet$ & Straub [1994] \\
& & Others (e.g., cellular) & $\bullet$ & Subramanian [1994] \\
& & & $\bullet$ & Kwon and Chidambaram [2000] \\
\hline
\end{tabular}




\begin{tabular}{|c|c|c|c|}
\hline $\begin{array}{l}\text { General Purpose } \\
\text { Systems }\end{array}$ & 28 & $\begin{array}{ll}\text { - } & \text { Windows } \\
\text { - } & \text { PC (or Microcomputer) } \\
\text { - } & \text { www(or e-commerce) } \\
\text { - } & \text { Computation } \\
& \text { Center } \\
\text { - } & \text { Groupware }\end{array}$ & $\begin{array}{ll}\text { - } & \text { Karahanna et al. [1999] } \\
\text { - } & \text { Igbaria et al.[1995], Agarwal \& } \\
& \text { Prasad [1999] } \\
\text { - } & \text { Gefen and Straub [2000] } \\
\text { - } & \text { Lucas and Spitler [1999, 2000] } \\
\text { - } & \text { Taylor and Todd [1995] } \\
\text { - } & \text { Lou et al. [2000] }\end{array}$ \\
\hline Office Systems & 27 & $\begin{array}{ll}\text { - } & \text { Word processor } \\
\text { - } & \text { Spreadsheet } \\
\text { - } & \text { Presentation S/W } \\
\text { - } & \text { Database programs } \\
\end{array}$ & $\begin{array}{l}\text { - } \text { Adams et al. [1992], Hubona and } \\
\text { - } \text { Geitz [1997] } \\
\text { - } \text { Methieson[1991],Venkatesh and } \\
\text { Davis[1996] } \\
\text { - } \quad \text { Doll et al. [1998], Hendrickson et al. } \\
\text { [1993] } \\
\text { - Szajna [1994], Doll et al. [1998] } \\
\text { - Malhotra and Galletta [1999],Lou et al. } \\
\text { [2000] }\end{array}$ \\
\hline $\begin{array}{l}\text { Specialized } \\
\text { Business } \\
\text { Systems }\end{array}$ & 25 & \begin{tabular}{|ll}
- & Computerized Model \\
- & Case Tools \\
- & $\begin{array}{l}\text { Hospital IS (Telemedi- } \\
\text { cine) }\end{array}$ \\
- & DSS, GSS, GDSS \\
- & Experts support System \\
- & Others (e.g. MRP) \\
\end{tabular} & 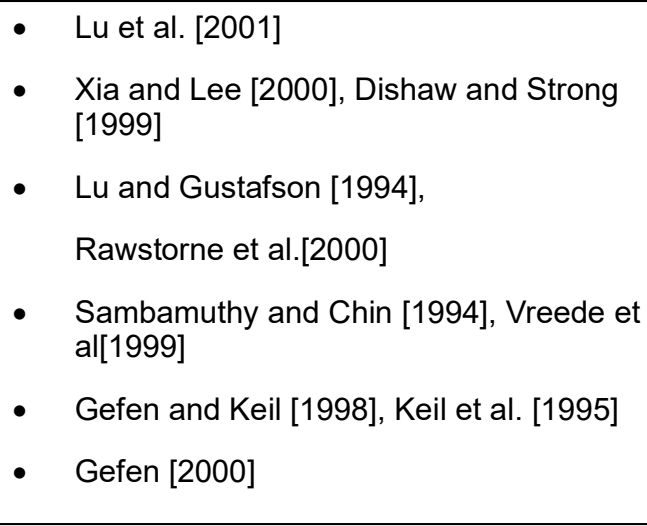 \\
\hline
\end{tabular}

Source : (Lee et al., 2003) 
Each of these constructs in the conceptual framework is defined and develop the theoretical rationale for the causal relationships of the model. The for the proposed is depicted in Table 2.

Table 2: Summary of the Operational Variables Construct

\begin{tabular}{|c|c|c|}
\hline $\begin{array}{l}\text { Variables } \\
\text { classification }\end{array}$ & $\begin{array}{l}\text { Variables/ } \\
\text { construct }\end{array}$ & Definition of construct \\
\hline \multirow{4}{*}{ 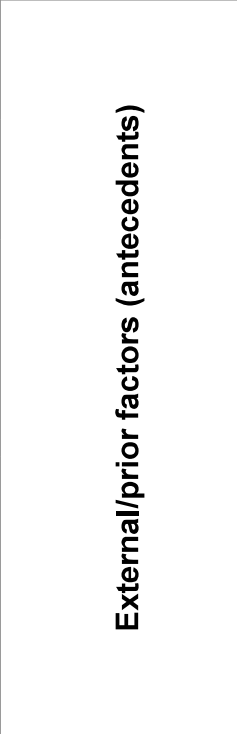 } & Subjective Norm & $\begin{array}{l}\text { a manager's perception that people who are important to her think } \\
\text { she should or should not use the technology (Chismar \& Wiley-Patton, } \\
\text { 2002) }\end{array}$ \\
\hline & Image & $\begin{array}{l}\text { the degree to which a manager believes that use of a new IT would } \\
\text { improve his or her status within a social group (Chismar \& Wiley-Patton, } \\
\text { 2002). }\end{array}$ \\
\hline & Computer self-efficacy & $\begin{array}{l}\text { Refers to manager's belief or perception that he or she owns the } \\
\text { capability to use computers in order to complete specific task (Bandura, } \\
\text { 1995). } \\
\text { Also paralleled with Ajzen (2002) who describes computer self- } \\
\text { efficacy as the ability to accomplish a specific behavior. }\end{array}$ \\
\hline & Awareness & $\begin{array}{l}\text { Manager's state or ability to perceive or to be conscious of presence or } \\
\text { importance of IT for better organization's operation. } \\
\text { adopted from (Song, 2014). } \\
\text { *awareness represented its perceived significance as an important } \\
\text { innovation, conceptual relationship with firm's competitive edge, and } \\
\text { appropriateness to the adoption behavior (Kim, 2004). }\end{array}$ \\
\hline 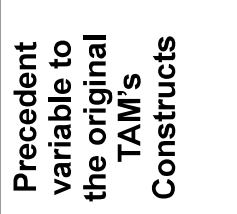 & Perceived usefulness & $\begin{array}{l}\text { as "the degree to which a person believes that using a particular system } \\
\text { would enhance his or her job performance or productivity" (Davis, 1985, } \\
\text { 1989; Venkatesh, 2000). }\end{array}$ \\
\hline \multirow{3}{*}{ 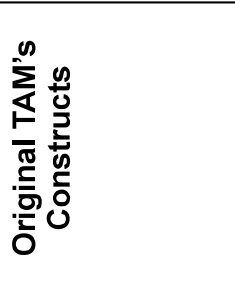 } & Perceived Ease of Use & $\begin{array}{l}\text { "the degree to which a person believes that using a particular system } \\
\text { would be free of effort, mentally and physically" (Davis, 1985, 1989). }\end{array}$ \\
\hline & Behavioral intention & $\begin{array}{l}\text { one's intention to perform a given behavior, a central factor of the TAM, } \\
\text { the theory of reasoned action, and the theory of planned behavior } \\
\text { (Ajzen, 1991) }\end{array}$ \\
\hline & Actual usage & $\begin{array}{l}\text { using a given IT systems routinely and productively (Thong \& Yap, } \\
\text { 1995) }\end{array}$ \\
\hline
\end{tabular}



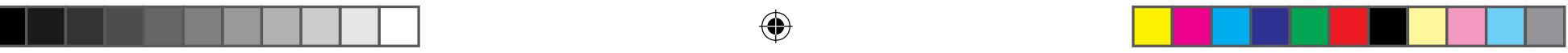

\begin{tabular}{|c|c|c|}
\hline 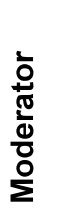 & $\begin{array}{l}\text { Top Management } \\
\text { Supports }\end{array}$ & $\begin{array}{l}\text { boards of directors, who make important decisions and hold position at } \\
\text { the highest ranking in a cooperative organizational structure }\end{array}$ \\
\hline 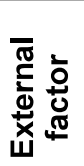 & Business performance & $\begin{array}{l}\text { non-financial performance i.e. operational performance (Chairoel et } \\
\text { al., 2015), has typically been reflected by cost reduction, productivity } \\
\text { improvement, organization's capabilities, resources expertise, and the } \\
\text { like. }\end{array}$ \\
\hline
\end{tabular}

\subsection{Conclusion}

The literature review has enabled the formation of the conceptual framework needed to study the innovation impact through IT adoption in the cooperative business process. Despite the potential benefits promised by the IT advancement, to date the cooperatives sector does not show a strong adoption of this technology. Other business sectors seems to have benefited most from the IT advancement, such as online retailing, service providers and to some extent the IT advancement have turn some businesses around substantially such as travel agencies, airlines, musics and others. It is time to explore the extent of IT adoption in the cooperative sector, what factors may contribute to allow its adoption and potential benefits that can be obtained by cooperatives through the IT adoption using the framework developed in this study.

\section{Reference}

A. H. Mutia Sobihah, Ahmad Munir Mohd Salleh Embat, W. Abd Aziz W. Mohd Amin, \& Mohamad Saladin Muda. (2014). The Relationship between E-Commerce Adoption and Organization Performance. International Journal of Business and Management, 9(1). doi:10.5539/ijbm.v9n1p56

Abbasi, M. S., Tarhini, A., Hassouna, M., \& Shah, F. (2015). Social, Organizational, Demography and Individuals' Technology Acceptance Behavior : A Conceptual Model. European Scientific Journal, 11(9).

Abd. Rahim Ahmad. (2006). Agricultural Cooperatives in Malaysia: Innovations and Opportunities in the 
Process of Transition towards the 21st Century Model. Paper presented at the 2006 FFTC-NACF International Seminar on Agricultural Cooperatives in Asia: Innovations and Opportunities in the 21st Century, , Seoul, Korea.

Abdul Jumaat Mahajar, \& Jasmani Mohd Yunus. (2005). Internationalisation of Kedah's Cooperative Societies. Problems and Perspectives in Management, 4.

Agarwal, R., Ahuja, M., Carter, P. E., \& Gans, M. (1998). Early and Late Adopters of IT Innovations: Extensions to Innovation Diffusion Theory.

Agarwal, R., \& Prasad, J. (1998a). The Antecedents and Consequents of User Perceptions in Information Technology Adoption. Decision support systems, 22(1), 15-29.

Agarwal, R., \& Prasad, J. (1998b). A Conceptual and Operational Definition of Personal Innovativeness in the Domain of Information Technology. Information Systems Research, 9(2), 204-215. doi:10.1287/isre.9.2.204

Aguinis, H., Edwards, J. R., \& Bradley, K. J. (2016). Improving Our Understanding of Moderation and Mediation in Strategic Management Research. Organizational Research Methods. doi:10.1177/1094428115627498

Ajzen, I. (1991). The Theory of Planned Behavior. Orgazational Behavior and Human Decision Process, 50.

Ajzen, I. (2002). Perceived Behavioral Control, Self-Efficacy, Locus of Control, and the Theory of Planned Behavior. Journal ofApplied Social Psychology, 32(4).

Al-Mamary, Y. H., Shamsuddin, A., \& Aziati, N. (2014). Factors Affecting Successful Adoption of Management Information Systems in Organizations towards Enhancing Organizational Performance. American Journal of Systems and Software, 2(5). doi:10.12691/ajss-2-5-2

AISamydai, M. J. (2014). Adaptation of the Technology Acceptance Model (TAM) to the Use of Mobile Banking Services. International Review of Management and Business Research.

Amirkhani, A., Salehahmadi, Z., Kheiri, E., \& Hajialiasgari, F. (2011). The TAM Models Application in Technology Transition. ijcrb.webs.com, Vol 3, No 3(July 2011).

Azmah Othman, \& Fatimah Kari. (2008). Enhancing Co-operative Movement to Achieve Malaysia's Development Goals. Paper presented at the ICA Research Conference : The Role of Co-operatives in Sustaining Development and Fostering Social Responsibility, Riva del Garda, Trento, Italy.

Azmah Othman, Fatimah Kari, Rohana Jani, \& Rosita Hamdan. (2012). Factors Influencing Cooperative 
Membership and Share Increment: An Application of the Logistic Regression Analysis in the Malaysian Cooperatives. World Review of Business Research, 2(5).

Bandura, A. (1995). Self-Efficacy in Changing Societies

Barnes, D., \& Matthew Hinton, C. (2012). Reconceptualising e-business performance measurement using an innovation adoption framework. International Journal of Productivity and Performance Management, 61(5), 502-517. doi:10.1108/17410401211232948

Bayo-Moriones, A., Billon, M., \& Lera-Lopez, F. (2013). Perceived Performance Effects of ICT in Manufacturing SMEs. Industrial Management \& Data Systems, 113(1), 117-135. doi:10.1108/02635571311289700

Bond, J. K. (2009). Cooperative Financial Performance and Board of Director Characteristics: A Quantitative Investigation. Journal of Cooperatives, 22, 22-24.

Bonus, H. (1986). The Cooperative Association as a Business Enterprise : A Study in the Economic Transactions. Journal of Institutional and Theoretical Economics (JITE), 142(2).

Borton, J. M. (1993). Information Technology Adoption and Implementation : A Longitudinal Multimethod Case Study. (Doctor of Philosophy), University of Colorado, Boulder.

Chairoel, L., Widyarto, S., \& Pujani, V. (2015). ICT adoption in affecting organizational performance among Indonesian SMEs. The International Technology Management Review, 5(2).

Che Mohd Zulkifli Che Omar, Osman Jusoh, Anas Tajudin, Ahmad Fadzli Ahmad Tajuddin, \& Nur Fadiah Abd Hadi. (2013). Entrepreneurial Culture from Islamic Perspective among Employees of Koperasi Kakitangan Angkasa Berhad (Kokita),Selangor, Malaysia. Journal of Islamic Business and Management, 3(2).

Cheuk, S. (2012). The Co-Operative Rating System and the Internal Management Factors Influencing the Performance of Co-operative in Sabah, Malaysia : An Exploratory Study Malaysian Accounting Review, 11(Special).

Chismar, W. G., \& Wiley-Patton, S. (2002). Result Demonstrability is the Tangibility of the Results of Using the Technology. Paper presented at the Proceedings of the 36th Hawaii International Conference on System Sciences.

Chuttur, M. Y. (2009). Overview of the Technology Acceptance Model: Origins,Developments and Future Directions. Sprouts.

Compeau, D. R., \& Higgins, C. A. (1997). Computer Self-Efficacy: Development of a Measure and Initial 
Test. MIS Quarterlly, 19(2).

Curl, J. (2010). The Cooperative Movement in Century 21. Affinities: A Journal of Radical Theory, Culture, and Action, 4(1).

Davis, F. D. (1985). A Technology Acceptance Model for Empirically Testing New End-User Information Systems Theory and Results. (Ph.D. in Management), Massachusetts Institute of Technology.

Davis, F. D. (1989a). Perceived Usefulness, Perceived Ease of Use and User Acceptance of Information Technology. MIS quarterly, 13(3), 319-340.

Davis, F. D. (1989b). Perceived Usefulness, Perceived Ease of Use, and User Acceptance of Information Technology. MIS quarterly, 13(5).

Davis, F. D. (1993). User Acceptance of Information Technology : Systems Characteristics, User Perceptions and Behavioural Impacts. Int Management Journal - Machine Studies.

Davis, F. D., Bagozzi, R. P., \& Warshaw, P. R. (1989). User Acceptance of Computer Technology: A Comparison of Two Theoretical Models. Management Science, 35(8), 982-1003. doi:10.1287/ mnsc.35.8.982

Dawes, J. (2007). Do data characteristics change according to the number of scale points used?

An experiment using 5-point, 7-point and 10-point scales. International Journal of Market Research, 50(1).

Ghobakhloo, M., Sabouri, M. S., Hong, T. S., \& Norzima Zulkifli. (2011). Information Technology Adoption in Small and Medium-sized Enterprises; An Appraisal of Two Decades Literature. Interdisciplinary Journal of Research in Business, 1(7), 53-80.

Gray, T. W., \& Kraenzle, C. A. (2002). Problems and Issues Facing Farmer Cooperatives (192). Retrieved from

Greenley, W. C. (2005). Software Adoption in Very Small Business: Testing a Research Model Based on the Technology Acceptance Model and the Theory of Planned Behavior.

Guislain, P., Qiang, C. Z.-W., Lanvin, B., Minges, M., \& Swanson, E. (2006). Information and Communications for Development Global Trends and Policies [Press release]

Hebert, M. B. (1994). Adopting information technology in hospitals: The relationship between attitudes/ expectations and behavior. Hospital \& Health Services Administration. 369-283.

Hitt, L. M., \& Brynjolfsson, E. (1996). Productivity, Business Profitability, and Consumer Surplus: Three Different Measures of Information Technology Value. MIS quarterly, 20(2), 121. 
Hollenstein, H. (2002). Determinants of the Adoption of Information and Communication Technologies (ICT): An Empirical Analysis Based on Firm-Level Data for the Swiss Business Sector. Paper presented at the DRUID Summer Conference on "Industrial Dynamics of the New and Old Economy - who is embracing whom?", Copenhagen.

Hunt, S. D., Richard D. Sparkman, J., \& Wilcox, J. B. (1982). The Pretest in Survey Research: Issues and Preliminary Findings. Journal of Marketing Research, 19(2).

Joseph, L. (2007). The Adoption and Diffusion of Computing and Internet Technologies in Historically Black Colleges and Universities. Walden University.

Junaidah Hashim. (2008). Factors Influencing the Acceptance of Web-Based Training in Malaysia: Applying the Technology Acceptance Model. International Journal of Training and Development, 12(4).

Khalil Md Nor, Shanab, E. A. A., \& Pearson, J. M. (2008). Internet Banking Acceptance in Malaysia Based on the Theory of Reasoned Action. Journal of Information Systems and Technology Management, $5(1)$.

King, W. R., \& Heb, J. (2006). A meta-analysis of the technology acceptance model. Information \& management, 43(6), 740-755. doi:10.1016/j.im.2006.05.003

Korpelainen, E. (2011). Theories of ICT System Implementation and Adoption - A Critical Review (Vol. 9). Finland: Aalto University.

L.Joyner, R., A.Rouse, W., \& A.Glatthorn, A. (2013). Writing the Winning Thesis or Dissertation : A Step by Step Guide. Singapore: Sage Publications Asia-Pacific Pte.Lte.

LALA, G. (2014). The Emergence and Development of the Technology Acceptance Model (TAM). Paper presented at the International Conference - Marketing - from information to decision.

Lee, Y., Kozar, K. A., \& Larsen, K. R. T. (2003). The Technology Acceptance Model: Past, Present, and Future. Communications of the Association for Information Systems, 12.

Legris, P., Ingham, J., \& Collerette, P. (2001). Why Do People Use Information Technology? A Critical Review of the Technology Acceptance Model. Information \& management.

Liang, T. P., \& Liu, C. c. (2010). A Resource-based Perspective on Information Technology and Firm Performance: A Meta Analysis. Industrial Management \& Data Systems, 110(8).

Lo'pez-Nicolas, C., Molina-Castillo, F. J., \& Bouwman, H. (2008). An Assessment of Advanced Mobile Services Acceptance: Contributions from TAM and Diffusion Theory Models. Information \& management, 45(6), 359-364. doi:10.1016/j.im.2008.05.001

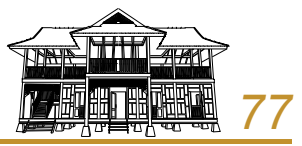


Lopez, D. A., \& Manson, D. P. (1997). A Study of Individual Computer Self-Efficacy and Perceived Usefulness of the Emowered Desktop Information System. Business Administration Computer Information Systems.

Lucchetti, R., \& Sterlacchini, A. (2004). The Adoption of ICT among SMEs: Evidence from an Italian Survey. Small Business Economics, 23

Madden, T. J., Ellen, P. S., \& Ajzen, I. (1992). A Comparison of the Theory of Planned Behavior and the Theory of Reasoned Action. Personality and Social Psychology Bulletin, 18(1), 3-9. doi:10.1177/0146167292181001

Malaysia Co-operative Societies Commission. (2012). ICA Committee on Consumer Cooperation for Asia and the Pacific.

Mao, E., \& Palvia, P. (2006). Testing an Extended Model of IT Acceptance in the Chinese Cultural Context. Database for Advances in Information Systems, 37(2).

Maslinawati Mohamad, \& Intan Waheedah Othman. (2013). Reputation and Transparency of Cooperative Movement in Malaysia. International Journal of Social, Behavioral, Educational, Economic and Management Engineering, 7(8).

Maslinawati Mohamad, Intan Waheedah Othman, \& Arun Mohamed. (2013). Accountability Issues and Challenges The Scenario for Malaysian Cooperative Movement. World Academy of Science, Engineering and Technology.

McBride, N., \& Wood-Harper, A. T. (2002). Towards User-Oriented Control of End-User Computing in Large Organizations T. Barrer (Ed.) Retrieved from https://books.google.com.my

McConnell, W. S. (2009). Technology Adoption : Influence of Availbility and Accessability. UNIVERSITY OF PHOENIX.

Melville, N., Kraemer, K. L., \& Gurbaxani, V. (2004). Information Technology and Organizational Performance: An Integrative Model of IT Business Value. MIS quarterly.

Mohd Khairuddin Hashim, \& Dzulhilmi Ahmad Fawzi. (2015). Issue, Scope and Focus of Research on Cooperatives in Malaysia. Journal of Education and Social Sciences, 2(Oct).

Mohd. Aminul Islam. (2012). An Appraisal of the Performance of Two (2) Development Financial Institutions (DFIS) in Malaysia. International Journal of Economics and Management Sciences, 1(7).

Napoleon, K. J. (1997). Improvement in Productivity and Quality from Information Technology - Worker Systems. (Doctor of Philosophy ), Georgia Institute of Technology, Georgia. 
Neeley, C. K. R. (2006). Connective technology adoption in the supply chain :The role of organizational, interorganizational and technology-related factors. University of North Texas.

Niehm, L. S., Tyner, K., Shelley, M. C., \& Fitzgerald, M. A. (2010). Technology Adoption in Small FamilyOwned Businesses: Accessibility, Perceived Advantage, and Information Technology Literacy. Journal of Family and Economic Issues, 31(4), 498-515. doi:10.1007/s10834-010-9197-0

Nurizah Noordin, Sushila Devi Rajaratnam, Mohd Shahron Anuar Said, Farahaini Mohd Hanif, \& Rafedah Juhan. (2012). Dividend and Profit Allocation Practices of Performing Cooperatives in Malaysia. Oñati Socio-Legal Series - Cooperatives and Collective Enterprise in the Social Economy, 22.

Nurjihan Idris, \& Amin Mahir Abdullah. (2011). Evaluation of Factors Affecting Agricultural Cooperatives Performance in Malaysia. Paper presented at the 2nd International Conference on Business and Economic Research.

Paopun, V. (2001). A Study of The Relationship Between Investment in Information Technology and Organizational Performance in the Thai Retail Industry. (Doctor of Business Administration.), Nova Southeastern University.

piaw, c. y. (2012). asas statistik penyelidikan. malaysia: McGraw-Hill (Malaysia) Sdn Bhd.

Pinsonneault, A., \& Kraemer, K. L. (1993). Survey Research Methodology in Management Information Systems : An Assesment. Journal of Management Information Systems, 10(2).

Qiang, C. Z.-W., Clarke, G. R., \& Halewood, N. (2006). The Role of ICT in Doing Business. Retrieved from

RADOMIR, L., \& NISTOR, V. C. (2013). An Application of Technology Acceptance Model to Internet Banking Services. Paper presented at the International Conference "Marketing - from information to decision" 6th Edition 2013.

Ramayah, T., \& Aafaqi, B. (2004). Role of Self-Efficacy in E-Library Usage Among Students of a Public University in Malaysia. Malaysian Journal of Library \& Information Science, 9(1).

Roelants, B., Hyungsik, E., \& Terrasi, E. (2014). Cooperatives and Employment: a Global Report.

Rogers, E. M. (1983). Diffusion of Innovations.

Rogers, E. M. (1995). Diffusion of Innovations. New York: The Free Press.

Rouibah, K. (2009). Intention to use Camera Mobile Phone before E-Shopping in the Arab world: Test of the Applicability of TAM 2. Paper presented at the International Conference Information Systems, Barcelona.

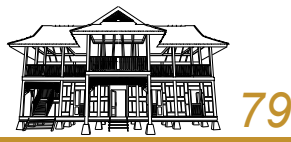


Rowley, J. (2014). Designing and Using Research Questionnaires. Management Research Review, 37(3), 308-330. doi:10.1108/MRR-02-2013-0027

Schepers, J., \& Wetzels, M. (2007). A meta-analysis of the technology acceptance model: Investigating subjective norm and moderation effects. Information \& management, 44, 90-103. doi:10.1016/j. im.2006.10.007

Shaffer, J. (1999). Historical dictionary of the cooperative movement: Scarecrow Press.

Shu-Hung Hsu. (2012). Effects of Competitive Strategy, Knowledge Management and E-Business Adoption on Performance. The Journal of Human Resource and Adult Learning, 8(2).

Song, C. (2014). Factors Influencing Micro Enterprises' InformationTechnology Adoption.

Sousa, K. J. (2003). Factors Influencing the Adoption of Electronic Business in the Purchasing Activities within a Business Organization Using an Extended Technology Acceptance Model. (PhD), University of Rhode Island.

Suhaimi Mhd Sarif, \& Yusof Ismail. (2010). Managerial Roles and the Training of Malaysian Co-operatives' Managers. Malaysian Journal of Co-operative Studies, 6.

Syed Shah Alam, \& Mohd. Kamal Mohammad Noor. (2009). ICT Adoption in Small and Medium Enterprises: An Empirical Evidence of Service Sectors in Malaysia. International Journal Business and Management, 4(2).

Thong, J., \& Yap, C. (1995). CEO characteristics, organizational characteristics and information technology adoption in small businesses.

Torgerson, R. E., Reynolds, B. J., \& Gray, T. W. (1997). Evolution of Cooperative Thought. Paper presented at the Cooperatives: Their Importance in the Future of the Food and Agricultural System, Las Vegas, NV, January 16-17, 1997.

Turnbow, J. L. (1996). The Relationship between Corporate Productivity and Information Technology Investment an Empirical Examination. . (Masters of Science in Information Systems), The University of Texas Arlington.

United Nations. (2011). Cooperatives in Social Development and Implementation of the International Year of Cooperatives. Retrieved from

Venkatesh, V. (2000). Determinants of Perceived Ease of Use: Integrating Control, Intrinsic motivation, and Emotion into the Technology Acceptance Model. Information Systems Research, 11(4), 342365. 


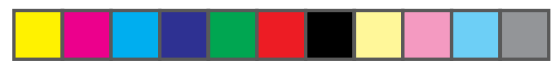

Venkatesh, V., \& Bala, H. (2008). Technology Acceptance Model 3 and a Research Agenda on Interventions. Decision sciences, 39(2).

Venkatesh, V., \& Davis, F. D. (2000). A Theoretical Extension of the Technology Acceptance Model: Four Longitudinal Field Studies. Management Science, 46(2), 186-204.

Venkatesh., Morris, V., Davis, M. G., \& Davis, G. B. (2003). User acceptance of information technology: Toward a unified view. . MIS Quarterlly, 27(3), 425-478.

Wiley-Patton, S. (2002). A Test of the Extended Technology Acceptance Model for Understanding the Internet Adoption Behavior of Physicians.

Williams, M. D., Dwivedi, Y. K., Lal, B., \& Schwarz, A. (2009). Contemporary trends and issues in IT adoption and diffusion research. Journal of Information Technology, 24(1), 1-10. doi:10.1057/jit.2008.30

Wu, M. Y., Chou, H. P., Weng, Y. C., \& Huang, Y. H. (2011). TAM2 based Study of Website User BehaviorUsing Web 2.0 Websites as an Example. Wseas Transactions on Business and Economics, 4(8).

Y.K.Chau, P. (2001). Influence of Computer Attitute and Self-Efficacy on IT Usage Behaviour. Journal of EndUser Computing.

Yousafzai, S. Y., Foxall, G. R., \& Pallister, J. G. (2007). Technology acceptance: a meta $\square$ analysis of the TAM: Part 1. Journal of Modelling in Management, 2(3), 251-280. doi:10.1108/17465660710834453

Yun, Y. (2013). Understanding Product Attachment and Expected Product Lifetime by Extending Technology Acceptance Model (TAM) with Product Personalization and Innovation Diffusion Theory (IRD). Michigan State University. 
